International Journal of Virology and Diseases
(ISSN:2637-6709)

\title{
Epidemiological Profile Of Congenital Syphilis In Alagoas
}

\section{Douglas Ferreira Rocha Barbosa ${ }^{1}$, Ediane Gonçalves ${ }^{2}$, Elias Neves do Nascimento Filho ${ }^{3}$,} Dara Moraes de Almeida ${ }^{4}$, Roberta Urtiga Malta ${ }^{5}$, Rosane Pereira dos Reis ${ }^{6}$.

${ }^{1,2,5}{ }^{6}$ Faculdade Estácio de Alagoas FAL; ${ }^{3 A}$ Ssociação Pestalozzi, ${ }^{4}$ Universidade Estadual de Ciências da Saúde de Alagoas - UNCISAL

\begin{abstract}
Objective: To analyze the epidemiological profile of congenital *Correspondence to Author: syphilis in the state of Alagoas from 2015 to 2019. Methods: Ep- Douglas Ferreira Rocha Barbosa idemiological study characterized as descriptive, observational, Faculdade Estácio de Alagoas FAL; retrospective and cross-sectional, carried out based on data collected from the Information System for Notifiable Diseases (SINAN) and made available by the Department of Chronic Conditions and Sexually Transmitted Infections. Results and DiscusHow to cite this article: sions: When observing the cases of congenital syphilis, 2019 Ediane Gonçalves, Elias Neves do saw a significant drop in cases compared to the years 2015 to Nascimento Filho, Dara Moraes 2018. Conclusion: It is concluded that the epidemiological profile de Almeida, Roberta Urtiga Malta, of DES demonstrates that the number of cases is higher among Rosane Pereira dos Reis.Epidemichildren under 7 days of age, the mother's age range between ological Profile Of Congenital Syph20 and 29 years, the mother's education level from 5th to 8th ilis In Alagoas. International Journal grade incomplete and race / color of the mother, brown. This of Virology and Diseases, 2021, reflects for health professionals to seek more strategies to eradi- 4:15. cate the disease in the state and in Brazil.
\end{abstract}

Keywords: Congenital syphilis, Epidemiology, Interdisciplinary Research.

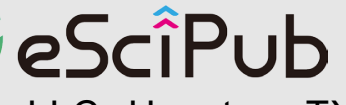
eSciPub LLC, Houston, TX USA. Website: http://escipub.com/ 


\section{INTRODUCTION}

Syphilis is a sexually transmitted infection (STI) with the bacterium Treponema pallidum as its agent. When the infection reaches pregnant women who do not perform the treatment or do it inadequately, the disease can be transmitted to the fetus and is called congenital syphilis (SC). Vertical transmission of syphilis can occur at any time during pregnancy or during delivery ${ }^{(1)}$.

CS is a disease that can be prevented, as long as the pregnant woman is diagnosed and the appropriate treatment is performed early. However, it still remains a public health problem and its occurrence shows several failures of health services, in particular that of prenatal care, in relation to which the diagnosis and treatment of syphilis among pregnant women are simple and also effective $^{(2)}$.

In 2015, Brazil had an incidence rate of CS of 6.5 cases (thousand live births) compared to 2006, in which the rate was 2 cases (thousand live births). This increase was similar to the mortality rate due to SC. In 2006 , the country had a rate of 2.3 deaths (100 thousand live births) and increased to 7.4 deaths in 2015. In the United States, the rate increased from 8.4 cases per (thousand live births) in the years 2008 to 2012 to 11.6 cases in 2014(3)

The diagnosis of syphilis is first performed by a clinical evaluation that includes complete anamnesis and physical examination that is able to identify the presence of the signs and symptoms of the disease. In screening, nontreponemal tests (VDRL and RPR - Rapid Plasma Reagin) are generally used(4).

Penicillin is the only antimicrobial agent that is effective in preventing vertical transmission of syphilis and treating fetal infection. Pregnant women receive the penicillin treatment regimen appropriate for the stage of the infection and if the therapy dose is not administered for latent syphilis, the complete treatment regimen will be repeated. Pregnant women who have a history of allergy to penicillin should be desensitized and treated with penicillin itself, as effective treatment for mother and fetus ${ }^{(5)}$.

Some studies have shown that the incidence of SC is higher in populations with less education, people of socioeconomically disadvantaged race / color (blacks) and who have worse living conditions ${ }^{(6)}$.

This study is relevant for health professionals who work directly in prenatal care to seek better strategies to eradicate SC in the state, in addition to offering comprehensive and comprehensive care.

The guiding question of this study was: what is the epidemiological profile of congenital syphilis in the state of Alagoas? And it aims to: analyze the epidemiological profile of congenital syphilis in the state of Alagoas in the period 2015-2019.

\section{METHODS}

Epidemiological study characterized as descriptive, observational, retrospective and cross-sectional, carried out based on data collected from the Information System for Notifiable Diseases (SINAN) and made available by the Department of Chronic Conditions and Sexually Transmitted Infections, through the page http: // indicatoressifilis.aids.gov.br/ in the period of October 2020. The study included cases of congenital syphilis reported in the State of Alagoas, between 2015 and 2019. In this study, the numbers and percentage distribution of cases of congenital syphilis according to rate incidence (per 1,000 live births), child's age, mother's age group, mother's education and mother's race or color.

As an exclusion criterion, data that were incomplete were used. To organize and 
tabulate the data, the Microsoft $\AA$ Excel $\AA$ 2010 program was used, in order to ascertain the relevant aspects of the research. It is noteworthy that according to Resolution No. 510/2016 of the National Health Council, as it is a system in the public domain and not subject to identification of the subjects, there was no need for consideration by the Research Ethics Committee (REC).

\section{RESULTS}

When analyzing the cases of congenital syphilis according to the child's age, the diagnosis is made in most cases in children younger than 7 days (Table 1).

Table 1 - Cases and percentage distribution of congenital syphilis according to the child's age by year of diagnosis. Alagoas, 2015-2019.

\begin{tabular}{cccccc}
\hline Child's Age & $\mathbf{2 0 1 5}$ & $\mathbf{2 0 1 6}$ & $\mathbf{2 0 1 7}$ & $\mathbf{2 0 1 8}$ & $\mathbf{2 0 1 9}$ \\
& $\%$ & $\%$ & $\%$ & $\%$ & $\%$ \\
\hline $\begin{array}{c}\text { Less than } 7 \\
\text { days }\end{array}$ & 371 & 296 & 328 & 407 & 188 \\
7 to 27 days & $66,4 \%$ & $92,2 \%$ & $95,1 \%$ & $92,1 \%$ & $89,1 \%$ \\
& $1,6 \%$ & 21 & 11 & 31 & 19 \\
28 to 364 & 8 & $6,5 \%$ & $3,2 \%$ & $7,0 \%$ & $9,0 \%$ \\
days & $2,1 \%$ & 3 & 4 & 2 & 3 \\
1 year & - & $0,9 \%$ & $1,2 \%$ & $0,5 \%$ & $1,4 \%$ \\
& & 1 & 2 & 2 & 1 \\
2 to 4 years & - & $0,3 \%$ & $0,6 \%$ & $0,5 \%$ & $0,5 \%$ \\
5 to 12 years & - & - & - & - & - \\
\hline
\end{tabular}

Source: MS/SVS/DCCI - Departamento de Doenças de Condições Crônicas e Infecções Sexualmente Transmissíveis.

Regarding congenital syphilis according to the mother's age group in Alagoas, we observed that the number of the disease is higher among those aged 20 to 29 years (Table 2).

Regarding the mother's education level, the number of cases of congenital syphilis is higher among those with incomplete 5 th to 8th grade (Table 3 ).

In comparison to the number of cases according to the mother's race or color, we observed that the rate is higher among women of mixed race/brown color (Table 4).

\section{DISCUSSION}

The epidemiological profile of congenital syphilis in the state of Alagoas according to the mother's age group is higher among women aged 20 to 29 years, with a greater number in 2016 with 165 (51.4\%) of the registered cases. The same is observed throughout the national territory, in which a study pointed out that in Brazil, the largest number of cases was also found among women aged 20 to 29 years, in 2014, with $5,849(50.8 \%)$ cases $^{(7)}$.

Regarding the child's age at the time of diagnosis of CS, the number of cases is mostly higher among children under 7 days of age. When observing its highest index, we have 2018 with 407 (92.1\%) of the confirmed 
cases in Alagoas. The same is repeated in old, 1722 (96.6) of the cases were the state of Goiás, where between the years confirmed(8).

2015 to 2018, among children under 6 days

Table 2 - Cases and percentage distribution of congenital syphilis according to the mother's age group by year of diagnosis. Alagoas, 2015-2019.

\begin{tabular}{cccccc}
\hline $\begin{array}{c}\text { Mother's } \\
\text { Age Group }\end{array}$ & $\begin{array}{c}\mathbf{2 0 1 5} \\
\%\end{array}$ & $\begin{array}{c}\mathbf{2 0 1 6} \\
\%\end{array}$ & $\begin{array}{c}\mathbf{2 0 1 7} \\
\%\end{array}$ & $\begin{array}{c}\mathbf{2 0 1 8} \\
\%\end{array}$ & $\begin{array}{c}\mathbf{2 0 1 9} \\
\%\end{array}$ \\
\hline 10 to 14 & 8 & 7 & 10 & 7 & - \\
years & $2,1 \%$ & $2,2 \%$ & $2,9 \%$ & $1,6 \%$ & \\
15 to 19 & 127 & 90 & 100 & 130 & 62 \\
years & $33,0 \%$ & $28,0 \%$ & $29,0 \%$ & $29,4 \%$ & $29,4 \%$ \\
20 to 29 & 186 & 165 & 170 & 211 & 104 \\
years & $48,3 \%$ & $51,4 \%$ & $49,3 \%$ & $47,7 \%$ & $49,3 \%$ \\
30 to 39 & 51 & 43 & 49 & 61 & 23 \\
years & $13,2 \%$ & $13,4 \%$ & $14,2 \%$ & $13,8 \%$ & $10,9 \%$ \\
40 years or & 7 & 5 & 6 & 12 & 1 \\
more & $1,8 \%$ & $1,6 \%$ & $1,7 \%$ & $2,7 \%$ & $0,5 \%$ \\
\hline
\end{tabular}

Source: MS/SVS/DCCI - Departamento de Doenças de Condições Crônicas e Infecções Sexualmente Transmissíveis.

Table 3 - Cases and percentage distribution of congenital syphilis according to mother's education by year of diagnosis. Alagoas, 2015-2019.

\begin{tabular}{cccccc}
\hline $\begin{array}{c}\text { Mother's } \\
\text { Schooling }\end{array}$ & $\begin{array}{c}\mathbf{2 0 1 5} \\
\%\end{array}$ & $\begin{array}{c}\mathbf{2 0 1 6} \\
\%\end{array}$ & $\begin{array}{c}\mathbf{2 0 1 7} \\
\%\end{array}$ & $\begin{array}{c}\mathbf{2 0 1 8} \\
\%\end{array}$ & $\begin{array}{c}\mathbf{2 0 1 9} \\
\%\end{array}$ \\
\hline Illiterate & 15 & 8 & 5 & 9 & 3 \\
& $3,9 \%$ & $2,5 \%$ & $1,4 \%$ & $2,0 \%$ & $1,4 \%$ \\
5th to 8th & 142 & 83 & 126 & 142 & 60 \\
grade & $36,9 \%$ & $25,9 \%$ & $36,9 \%$ & $32,1 \%$ & $28,4 \%$ \\
incomplete & & & & & \\
Complete & 25 & 24 & 24 & 38 & 19 \\
Elementary & $6,5 \%$ & $7,5 \%$ & $7,0 \%$ & $8,6 \%$ & $9,0 \%$ \\
Incomplete & 24 & 30 & 30 & 32 & 25 \\
Medium & $6,2 \%$ & $9,3 \%$ & $8,7 \%$ & $7,2 \%$ & $11,8 \%$ \\
High School & 30 & 32 & 38 & 68 & 20 \\
& $7,8 \%$ & $10,0 \%$ & $11,0 \%$ & $15,4 \%$ & $9,5 \%$ \\
Incomplete & 1 & 5 & 3 & 2 & - \\
higher & $0,3 \%$ & $1,6 \%$ & $0,9 \%$ & $0,5 \%$ & \\
Graduated & 4 & 1 & 2 & 5 & 1 \\
& $1,0 \%$ & $0,3 \%$ & $0,6 \%$ & $1,1 \%$ & $0,5 \%$ \\
\hline
\end{tabular}

Source: MS/SVS/DCCI - Departamento de Doenças de Condições Crônicas e Infecções Sexualmente Transmissíveis. 
Table 4 - Cases and percentage distribution of congenital syphilis according to mother's race or color by year of diagnosis. Alagoas, 2015-2019.

\begin{tabular}{cccccc}
\hline $\begin{array}{c}\text { Race or } \\
\text { Color of } \\
\text { Mother }\end{array}$ & $\begin{array}{c}\mathbf{2 0 1 5} \\
\%\end{array}$ & $\begin{array}{c}\mathbf{2 0 1 6} \\
\%\end{array}$ & $\begin{array}{c}\mathbf{2 0 1 7} \\
\%\end{array}$ & $\begin{array}{c}\mathbf{2 0 1 8} \\
\%\end{array}$ & $\begin{array}{c}\mathbf{2 0 1 9} \\
\%\end{array}$ \\
\hline White & 14 & 22 & 13 & 24 & 4 \\
& $3,6 \%$ & $6,9 \%$ & $3,8 \%$ & $5,4 \%$ & $1,9 \%$ \\
Black & 13 & 16 & 9 & 7 & 7 \\
& $3,4 \%$ & $5,0 \%$ & $2,6 \%$ & $1,6 \%$ & $3,3 \%$ \\
Yellow & 1 & 1 & - & - & - \\
& $0,3 \%$ & $0,3 \%$ & & & 168 \\
Parda & 334 & 255 & 307 & 375 & $79,6 \%$ \\
& $86,8 \%$ & $79,4 \%$ & $89,0 \%$ & $89,8 \%$ & - \\
\hline Indigenous & - & 1 & - & 2 & $0,5 \%$ \\
\hline
\end{tabular}

Source: MS/SVS/DCCI - Departamento de Doenças de Condições Crônicas e Infecções Sexualmente Transmissíveis.

When analyzing the SC according to the mother's schooling, women with 5th to 8th grade incomplete fit as the highest index number registered, with $142(36.9 \%)$ of the cases in 2015 and a considerable drop in $2019,60(28.4 \%)$ of confirmed cases. In the city of Cascavel-PR, the SC according to the mother's education, has the highest number among the illiterate, having in 2015, 6 $(27.3 \%)$ of the cases $^{(9)}$.

According to the mother's race or color, in the state of Alagoas, brown color / race leads the number of cases, only in 2015 were 334 $(86.8 \%)$ of the confirmed cases, against 1 $(0.3 \%)$ cases of women of color / yellow race. In the city of Sobral-CE, we observed the same result, mothers of color / brown race, leads the number of cases, in the years 2017 to 2013 there were 111 (92.5\%) of the cases $^{(10)}$.

\section{CONCLUSION}

It is concluded that the epidemiological profile of DES demonstrates that the number of cases is higher among children under 7 days of age, the mother's age range between 20 and 29 years, the mother's education level from 5th to 8th grade incomplete and race/color of the mother, brown.

This reflects for health professionals to seek more strategies to eradicate the disease in the state and in Brazil, strategies such as: active search of pregnant women, early diagnosis, appropriate treatment of the disease for both the pregnant woman and her partner and better information about the disease. As a result, the number of cases of SC may be reduced to ever lower rates so that there is total eradication of the disease.

\section{REFERENCES}

[1]. Moreira CFA, Oliveira DM, Alencar LN, Cavalcante DFB, Pinheiro AS, Orfão NH. Perfil dos casos notificados de sífilis congênita. Cogitare Enfermagem.2017; 22(2). 
[2]. Cooper JM, Michelow IC, Wozniak PS, Sánchez PJ. Em tempo: a persistência da sífilis congênita no Brasil-Mais avanços são necessários. Revista Paulista de Pediatria. 2016; 34(3):251-253. DOI: https://doi.org/10.1016/j.rppede.2016.06.0 04.

[3]. Reis GJ, Barcellos C, Pedroso MM, Xavier DR. Diferenciais intraurbanos da sífilis congênita: análise preditiva por bairros do Município do Rio de Janeiro, Brasil. Cadernos de Saúde Pública. 2018; 34 (9). DOI: 10.1590/0102-311X00105517.

[4]. Guimarães TA, Alencar LCR, Fonseca LMB, Gonçalves MMC, Silva MP. Sífilis em gestantes e sífilis congênita no Maranhão. Arquivos de Ciências da Saúde. 2018; 25(2): 24-30. DOI: https://doi.org/10.17696/2318-

3691.25.2.2018.1023.

[5]. Motta IA, Delfino IRS, Santos LV, Morita MO, Gomes RGD, Martins TPS, et. al. Sífilis congênita: por que sua prevalência continua tão alta. Rev Med Minas Gerais. 2018; 28(6):45-52. DOI: http://www.dx.doi.org/10.5935/22383182.20180102.

[6]. Azevedo AC, Drumond EF, Gonçalves RV, Machado CJ. Evolução da qualidade das informações das declarações de óbito com menções de sífilis congênita nos óbitos perinatais no Brasil. Cadernos Saúde Coletiva. 2017; 25(3):259-267. DOI: 10.1590/1414-462X201700030214.

[7]. Souza WN, Benito LAO. Perfil epidemiológico da sífilis congênita no Brasil no período de 2008 a 2014. Universitas: Ciências da Saúde. 2016;14(2):97-104. DOI: $10.5102 /$ ucs.v14i2.3811.

[8]. Souza RR, Silva PI, Oliveira DL, Nascimento MA, Carvalho VM, Albuquerque CAN, et. al. Perfil de Casos Notificados de Sífilis Congênita no Estado de Goiás entre 2015 a 2018. Brazilian Journal of Development. 2020;6(7): 4871548725. DOI:10.34117/bjdv6n7-497.

[9]. Cardoso A, Griep R. Perfil epidemiológico da sífilis congênita no município de cascavel/PR no ano de 2015. Revista Thêma et Scientia. 2017;7(1):143-155.

[10]. Rodrigues IM, Ribeiro MA, Albuquerque IMN, Dias LKS, Aguiar NLT, Lima DS. Perfil e distribuição espacial da sífilis congênita em Sobral-CE no período de 2007 a 2013. Ciência \& Saúde. 2018;11(2):70-76.
DOI: $\quad$ https://doi.org/10.15448/1983652X.2018.2.26316. 